\title{
THE CHALLENGING TASK OF GOVERNING CROSS-BORDER INVESTMENT IN PERIPHERAL REGIONS: POLISH INVESTORS IN NORTHEAST GERMANY
}

\author{
Sebastian Kinder ${ }^{1}$, Kamil Lis ${ }^{1}$, Wolfdietrich PeikeR ${ }^{2}$, Lech Suwala ${ }^{2}$ \\ ${ }^{1}$ Economic Geography, Eberhard Karls University in Tübingen, Germany \\ ${ }^{2}$ Economic Geography, Humboldt University in Berlin, Germany \\ Manuscript received: October 18, 2013 \\ Revised version: March 7, 2014
}

Kinder S., Lis K., PeiKer W., Suwala L. 2014. The challenging task of governing cross-border investment in peripheral regions: Polish investors in northeast Germany. Quaestiones Geographicae 33(4), Bogucki Wydawnictwo Naukowe, Poznań, pp. 27-41, 2 maps, 4 tables, 3 figs. DOI 10.2478/quageo-2014-0047, ISSN 0137-477X.

\begin{abstract}
AвSTRACт: The article investigates the challenging task of governing cross-border investment in peripheral regions. The main objective is to identify common opportunities and obstacles in the Pomerania Euroregion by taking the case study of Polish citizens/ entrepreneurs investing in northeast Germany. This relatively new phenomenon is accompanied by large uncertainties and risks, and lacks further empirical insights. At the same time it breaks new ground, creates alternatives, calls for the development of efficient modes of cross-border cooperation and addresses mutual governance issues on an inter-regional basis between manifold stakeholders on both sides of the border. The case study summarises findings from fieldwork, elaborates a quantitative and qualitative assessment of cross-border governance measures within formal and informal institutions, and tries to formulate policy recommendations for prospective approaches.
\end{abstract}

KEY WORDS: governance, cross-border regions, FDI, Germany, Poland

Address of the corresponding author: Sebastian Kinder, Eberhard Karls University in Tübingen, Chair in Economic Geography, Rümelinstraße 19-23, 72070 Tübingen, Germany; e-mail: sebastian.kinder@uni-tuebingen.de

\section{Introduction}

Germany and Poland are not only neighbouring countries in the European Union, but also close trading partners. A detailed look at Poland's trade balance reveals that Germany is by far its most important trade partner accounting for approximately one forth of its trade volume with a relatively even balance (Deutsche Bunde bank 2012; GUS 2012)․․ Even so, the statistics of

1 However, there are some statistical ambiguities between German and Polish data due to asymmetries stemming from different methodologies applied. A significant part of German exports to Poland is channelled through German harbours; these include also goods originating, e.g., from China and declared af- bilateral foreign direct investment (FDIs) tell a different story. Whereas the cumulative inward FDIs from Germany to Poland between 1993 and 2010 amounted to 22 billion Euro, only one billion Euro was invested in the opposite direction during the same time period (Robak 2011: 10;

terwards as "German goods". Another issue is the large amount of re-exports (including goods such as automotive parts, textiles, apparel) initially imported to Germany and then exported again. This creates discrepancies between the countries of origin and destination. Therefore, the Polish Central Statistical Office (GUS) reports a lower value for German imports to Poland (e.g. €34 billion, 2011) than the German Federal Statistical Office (Statistisches Bundesamt) for German exports to Poland (€43.5 billion, 2011) (Botschaft... 2012: 4). 
Table 1. Bilateral FDI between Germany and Poland, 2008-2011 (in billion Euro).

\begin{tabular}{|c|c|c|}
\hline Year & $\begin{array}{c}\text { German FDIs in } \\
\text { Poland }\end{array}$ & $\begin{array}{c}\text { Polish FDIs in } \\
\text { Germany }\end{array}$ \\
\hline 2008 & $€ 1.08$ billion & $€ 0.21$ billion \\
\hline 2009 & $€ 2.14$ billion & $€ 0.12$ billion \\
\hline 2010 & $€ 2.19$ billion & $€ 0.30$ billion \\
\hline 2011 & $€ 2.99$ billion & $€ 0.41$ billion \\
\hline
\end{tabular}

Source: Bundesbank 2012: 14,17,20,28,31.

Botschaft... 2012: 5). Interestingly, current data show a promising rising trend of Polish FDIs in Germany between 2008 and $2011^{2}$ (Table 1).

We want to explore this phenomenon at a much smaller scale by taking a closer look at Polish FDIs in the north-eastern region in Germany, especially in the former county (Landkreis) of Uecker-Randow ${ }^{3}$. We will focus on how this phenomenon is governed. We have chosen Uecker-Randow for the following three reasons: (1) its vicinity to the Pomerania Euroregion's only significant agglomeration of Szczecin in Poland (Maps 1 and 2), (2) the highest concentration of enterprises run by Polish owners, proprietors, or managing directors in the German part of the region (Table 2), and (3) a detailed media analysis preceding the project concerning Polish entrepreneurial activities (Neuser, Wicke 2013).

Since Uecker-Randow borders Poland and is located approximately $15 \mathrm{~km}$ west of the city centre of Szczecin and roughly $6 \mathrm{~km}$ from the city's outskirts, it is not surprising that the county sustains over three-fourths of Polish enterprises in the neighbouring German counties (Table 2). Although those 189 enterprises constitute only $6.5 \%$ of all enterprises $(=2,929)$ in this territory, some industries like construction, services or trade represent almost 10\% in their sectors (Statistisches

2 Being aware that FDI is a highly volatile phenomenon that might depend on individual large-scale investment projects in certain years, we want to investigate if this trend is the result of a small, but solid background in the Pomerania Euroregion with regard to the county (Landkreis) of Uecker-Randow.

3 Uecker-Randow was a county between 1994 and 2011 in the east of the German federal state (Bundesland) of Mecklenburg-Cispomerania bordering Poland (Map 1). The county reform (Kreisgebietsreform) of 2011 led to a consolidation and the creation of a new, larger county of Cispomerania-Greifswald encompassing the old counties of Uecker-Randow, Eastern Cispomerania and the Hanseatic City of Greifswald.

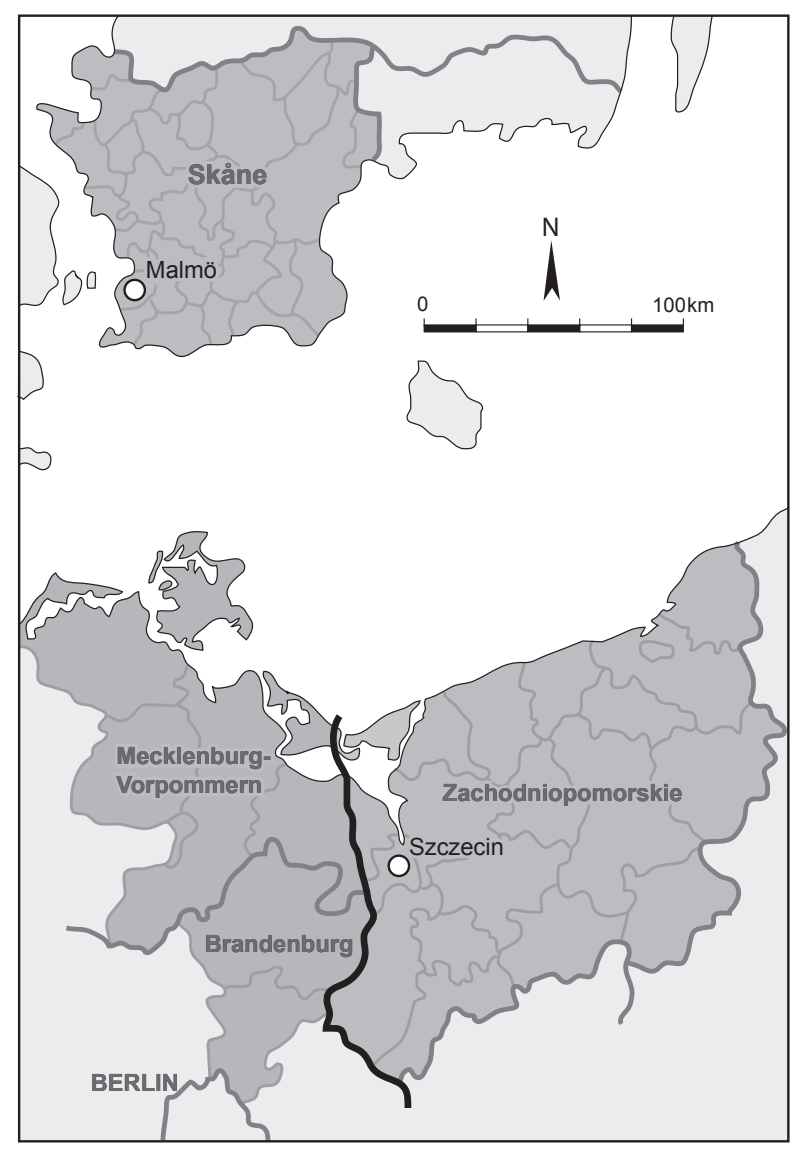

Map 1. Extent of the Pomerania Euroregion. Source: Pomerania 2013a.

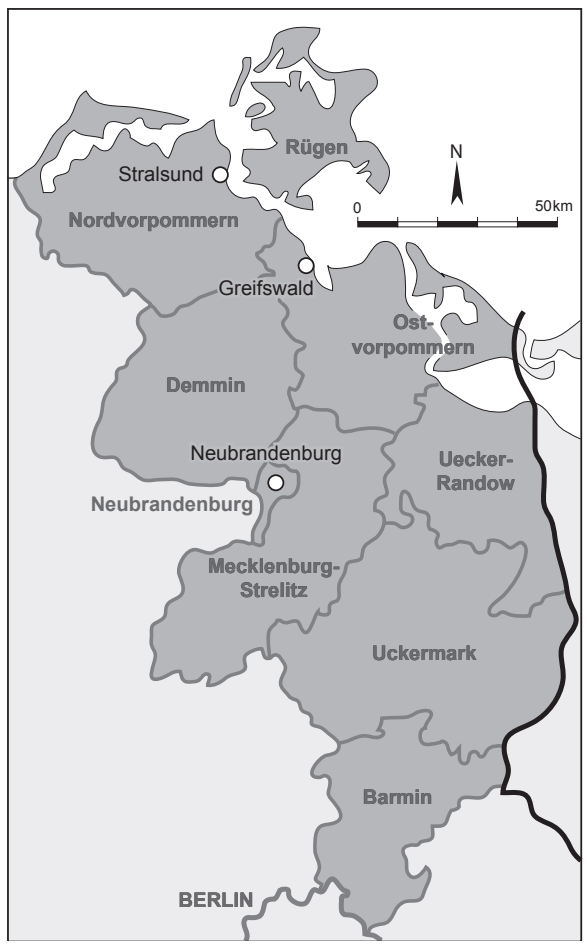

Map 2. Former German counties in the Pomerania Euroregion. Source: Pomerania 2013c. 
Table 2. Enterprises run by (a) foreign, (b) European Union, (c) Polish owners, proprietors, or managing directors in selected counties of the German part of the region, Sept. 2011.

\begin{tabular}{|c|c|c|c|c|c|c|c|}
\hline \multicolumn{8}{|c|}{ Foreign-run } \\
\hline Industry & $\mathrm{DM}$ & HGW & MST & NB & OVP & UER & Total \\
\hline Construction & 4 & 0 & 1 & 3 & 3 & 30 & 41 \\
\hline Services & 26 & 27 & 12 & 32 & 32 & 87 & 216 \\
\hline Tourism & 26 & 43 & 24 & 39 & 58 & 32 & 222 \\
\hline Trade & 29 & 28 & 35 & 37 & 39 & 93 & 261 \\
\hline Manufacturing & 2 & 3 & 6 & 4 & 10 & 15 & 40 \\
\hline Other & 7 & 0 & 4 & 0 & 7 & 1 & 19 \\
\hline Total - foreign & 94 & 101 & 82 & 115 & 149 & 258 & 799 \\
\hline \multicolumn{8}{|c|}{ European Union } \\
\hline Industry & $\mathrm{DM}$ & HGW & MST & NB & OVP & UER & Total \\
\hline Construction & 4 & 0 & 0 & 2 & 1 & 29 & 36 \\
\hline Services & 21 & 16 & 5 & 17 & 18 & 79 & 156 \\
\hline Tourism & 2 & 15 & 6 & 7 & 19 & 6 & 55 \\
\hline Trade & 18 & 11 & 20 & 21 & 20 & 77 & 167 \\
\hline Manufacturing & 1 & 1 & 6 & 4 & 7 & 12 & 31 \\
\hline Other & 7 & 0 & 2 & 0 & 7 & 1 & 17 \\
\hline Total - foreign & 53 & 43 & 39 & 51 & 72 & 204 & 462 \\
\hline \multicolumn{8}{|c|}{ Polish } \\
\hline Industry & $\mathrm{DM}$ & HGW & MST & NB & OVP & UER & Total \\
\hline Construction & 4 & 0 & 0 & 0 & 0 & 29 & 33 \\
\hline Services & 3 & 3 & 2 & 2 & 10 & 78 & 98 \\
\hline Tourism & 0 & 2 & 3 & 0 & 2 & 3 & 10 \\
\hline Trade & 3 & 2 & 5 & 3 & 7 & 57 & 87 \\
\hline Manufacturing & 0 & 0 & 0 & 0 & 2 & 12 & 14 \\
\hline Other & 5 & 0 & 0 & 0 & 0 & 0 & 5 \\
\hline Total - foreign & 15 & 7 & 10 & 5 & 21 & 189 & 247 \\
\hline
\end{tabular}

$\mathrm{DM}=$ Demmin, HGW = Hansestadt Greifswald, MST = Mecklenburg-Strelitz, NB = Neubrandenburg, OVP = Ostvorpommern, UER = Uecker Randow

Source: own compilation based on data from the Statistical Office of Mecklenburg-Cispomerania, 2012.

Amt... 2012). This data is also partly visible in the media (print, visual) by means of ambivalent headlines like "Help! The Poles are arriving!" (Kuiper 2007) or "East German village experiences an unexpected heyday with the assistance of Poles" (Trentmann 2011).

Concerning these facts, our main objective is to investigate the challenging task of governing cross-border Polish investment in Uecker-Randow. Most literature so far has concentrated either on general issues of cross-border regions (Schamp 1995; Kaczmarek, Stryjakiewicz 1997; Barjak 2001; Stryjakiewicz 2002; Krätke, Borst 2004, Virtanen 2004) or on the opposite direction of investment (e.g. foreign or German FDIs in Poland) between both countries (Maack et al. 2005; Maack 2010; Zimny 2012). This article aims to identify common opportunities and obstacles in the Pomerania Euroregion by taking the case study of Polish citizens/ entrepreneurs investing in Uecker-Randow. This relatively new phenomenon is accompanied by large uncertainties, risks and lacks empirical insights. At the same time it breaks new ground, creates alternatives, calls for the development of efficient modes of cross-border cooperation, and addresses mutual governance issues on an inter-regional basis between manifold stakeholders on both sides of the border. The case study summarises findings from fieldwork, elaborates a quantitative and qualitative assessment of cross-border governance measures within formal and informal institutions, and tries to formulate policy recommendations for prospective approaches based on general theoretical discussion of governance and empirical facts from Uecker-Randow. 


\section{Governance}

New governance modes experienced a tremendous interest in the wake of deregulation, liberalisation, privatisation and de-bureaucratisation triggered by the Washington Consensus in the 1990s and the dictum of the lean state (Fitoussi, Saraceno 2013). Governance is one of the most frequently discussed issues in contemporary literature on policy science (Kooiman 1993; Pierre 2000; Hirst 2000; Kjaer 2004; Schuppert 2005) and a promising field in human geography (Fürst 2003; Einig et al. 2005; Sparke 2006). The consequence is a wide variety of conceptualisations. However, governance is quite an elusive concept. There exists no common definition or a clearly distinguished governance theory. Many authors have attempted to provide an overview of different varieties, emphasising multiple differences and similarities (e.g. Fig. 1).

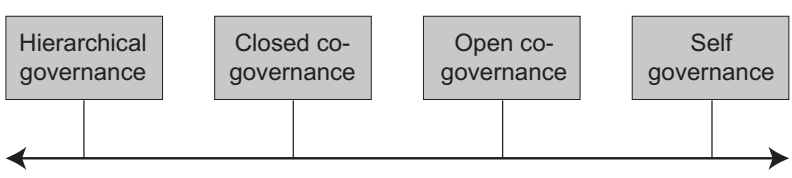

Fig. 1. Different types of governance (Kooimann 2003).

In general, governance pools groups of different institutions and actors that do not belong to the same government sphere. The term implies interdependence between the powers of institutions associated with collective action where autonomous actors' networks may intervene and agency is not entirely left to the state power or authority (Padioleau 2000: 69).

With regard to cross-border regions in the European Union, governance is a frequently-used notion to describe the mechanism of a territory being governed by a combination of manifold levels and types of governmental authorities operating in the same space. This challenging task was tackled by the creation of socalled Euroregions (sometimes also referred to as 'euregios' or 'euregions' - Kramsch, Hooper 2004) in the EU, which represent multilevel institutionalisation where member states rather than the European Commission (EC) are in charge of allocating funds according to the subsidiarity principle (Heddebaut 2004: 73). Euroregions aim to achieve greater integration by an adequate management of cross-border funding mechanisms (INTERREG, PHARE, SAPARD, ISPA and/or TACIS) on the basis of principles of 'partnership' and 'subsidiarity', transnational spatial planning, and inter-governmental frameworks envisioned as 'multi-level polities'. These frameworks are orchestrated by a multiplicity of actors including the EC, national governments, regional and local authorities, non-governmental organisations, associations, unions, educational institutions, public-private partnerships, and many other entities of the wider civil society (Hooghe, Marks 2001).

Although constructed after decades of experimentation in political, economic, social and cultural decentralisation at sub-national scales with sovereign member states, especially Euroregions in Central and East-European countries face multiple governance dilemmas and remain "laboratories of European integration" (Kramsch, Hooper 2004: 3). There are still plenty of obstacles inhibiting effective cross-border cooperation and mutual governance. They can be distinguished along the lines of legal, institutional, administrative, political, financial, monetary, socio-economic, and cultural problems (Ricq 1992). The balancing act of each region within European cross-border territories is to maintain its local identity while working in the national context and opening itself to benefits from transnational cooperation at the same time (Heddebaut 2004). This article highlights socio-economic obstacles when pursuing mutual governance in the Pomerania Euroregion between northwest Poland (West Pomeranian voivodeship) and northeast Germany (parts of the federal states of Mecklenburg-Cispomerania and Brandenburg) concerning cross-border investment of Polish citizens in Germany ${ }^{4}$.

\footnotetext{
4 The Pomerania Euroregion represents a special case and integrates three EU member states (Map 1). The Swedish Scania region has not been included into the study for several reasons: an increased complexity of governance modes, the special geographical setting (it is separated from Poland and Germany by the Baltic Sea), and poor connectivity (missing spatial proximity to the Szczecin agglomeration) with regard to the case study.
} 


\section{Demographic and economic situation in Uecker-Randow}

The former county of Uecker-Randow is located in the south-eastern corner of the German federal state of Mecklenburg-Cispomerania. It was administrated from Pasewalk, the largest town in the county. Currently, this region faces major demographic and economic challenges (Table 3). In 2009, the per capita income was at $60.7 \%$ of the German average, representing one of the lowest values nationwide. Simultaneously, the unemployment rate, which is more than twice as high as the rate of Germany, indicates a distinctly weak economic situation. Structural deficits in Uecker-Randow accelerated since the transformation of the state-commanded economy of the former German Democratic Republic (GDR) in the early 1990s. With the decline in economic performance and employment, especially young people seeking work emigrated from that region. Between 1990 and 2010, the population of Uecker-Randow shrank by $24.9 \%$, from 96,043 to 72,137 inhabitants. Thus, the demographic situation is characterised by a distinct ageing (Thiemann, Wockenfuß 2013).

The eastward enlargement of the European Union, including the extension of its Common Market area, offers new opportunities to that region, as it is no more situated at the border of the supranational entity. It therefore allows infinite possibilities for cross-border activities with the proximate city of Szczecin with roughly 400,000 inhabitants (GUS 2012: 655) and its agglomeration. Some Polish citizens even prefer to reside in Uecker-Randow due to cheaper rents than in Szczecin, helping both to decrease the vacancy rate of properties and compensate for the loss of inhabitants on the German side. This is a consequence of the agglomeration diseconomies on the Polish side of the border, such as an increased cost of living.

With regard to the economic challenges, hypothetically, self-employed Poles and investors may contribute to the regional per capita income, while investors may even create employment. Due to uncertainties and risks, especially for small and medium enterprises, also with regard to cultural and administrative distances, gov-
Table 3. Comparison of demographic and economic key data of Germany and of the county of Uecker-Randow.

\begin{tabular}{|l|c|c|c|}
\hline & $\begin{array}{c}\text { Per capita } \\
\text { income }\end{array}$ & $\begin{array}{c}\text { Unemployment } \\
\text { rate }\end{array}$ & $\begin{array}{c}\text { Share of pop- } \\
\text { ulation older } \\
\text { than 50 years }\end{array}$ \\
\hline $\begin{array}{l}\text { Uecker- } \\
\text { Randow }\end{array}$ & $\begin{array}{c}€ 17,633 \\
(2009)\end{array}$ & $17.6 \%$ (Jan. 2012) & $48.0 \%(2010)$ \\
\hline $\begin{array}{l}\text { Germany } \\
\text { (average) }\end{array}$ & $\begin{array}{c}€ 29,027 \\
(2009)\end{array}$ & $7.7 \%$ (Jan. 2012) & $40.0 \%(2010)$ \\
\hline
\end{tabular}

Source: own compilation based on data from Thiemann and Wockenfuß (2013).

ernance institutions can be considered to play a crucial role in successful investments in Uecker-Randow, and therefore in a possible development of that region. In the following, several relevant governance institutions are analysed on the basis of the supply of services for investors from Poland to Germany.

\section{Formal institutions in Cispomerania}

Although governance of a Euroregion includes influences from several governmental spheres, as mentioned above, initiatives from institutions at lower levels - due to the principle of subsidiarity - can often be seen as crucial and accessible ones for pioneers and private investors from Poland engaging in Germany. Due to this relatively new phenomenon and taking into account the complexity of governance modes, different administrative regions (in Germany, the very former county of Uecker-Randow, and in Poland) and levels as well as activity spheres (public-administrative vs. economic), we have developed a synopsis showing the numerous interrelationships between the stakeholders in the region involved (Fig. 2). Moreover, with special regard to bottom-up governance modes, we distinguish between formal and informal institutions. In our case study, we define formal institutions as officially registered organisations, associations, or administrative-governmental institutions that communicate their range of offers for potential investors in an explicit way, via websites, leaflets, and other advertising material. Informal institutions are individuals or groups that assist potential investors without explicitly offering services in the media but rather communicating them via personal networks. 


\section{The Pomerania Euroregion}

We start the analysis of relevant institutions governing our selected region with a closer look at the Pomerania Euroregion. This cross-border region is organised as an association of municipal administrations and other institutions in north-eastern Germany, north-western Poland and southern Sweden (Map 1, Fig. 2). Its main objective is to develop the bordering regions and to revive the "historically persistent" ties between those countries (Pomerania 2014). Be- sides supporting cross-border exchange between social and cultural associations embraced by the paradigm of "creating areas of border-crossing economy and services" (Pomerania 2014), economic development is one of the main targets of the Pomerania Euroregion. This objective can be realised by assistance for economic investments, development of regional infrastructure commonly funded by INTERREG-A programmes, and the creation of economic cooperation by means of know-how exchange via cross-border fairs and seminars. Although those economy-related activ-

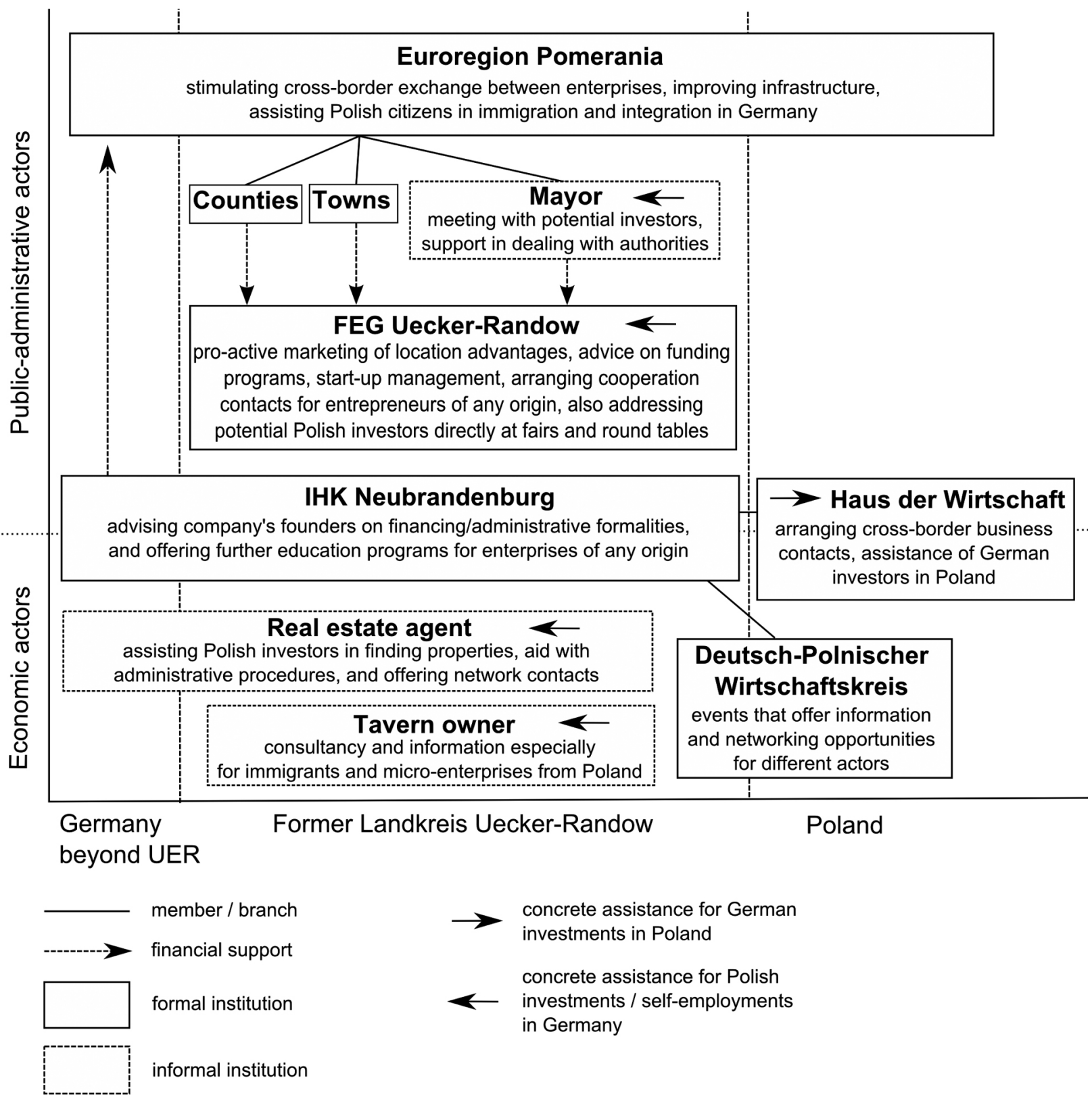

Fig. 2. Formal and informal institutions in Uecker-Randow and their services for Polish investors. Source: own compilation based on information from research. 
ities of the Euroregion are geared in particular towards small and medium-sized enterprises representative of most business entities (no matter whether German or Polish) of the region, they are not explicitly addressed towards Polish-owned enterprises operating in the German part of the region.

Furthermore, the establishment of German-Polish grammar schools like the one in the municipality of Löcknitz (Pomerania 2013a) may increase the attractiveness of living on the German side for Polish people. In a similar way, the contact and advice centre in Löcknitz may ease the immigration and social integration of Polish citizens in Germany. It assists Poles in administrative procedures and the search for housing, language courses and schools (Pomerania 2013b). This integration assistance, together with social and cultural exchanges, may bridge cultural margins between both countries and therefore increase the willingness for Polish citizens to move to Germany where they might find small enterprises or become self-employed. It can already be stated at this point that these formal institutions lack concrete assistance needed with the regional economy for the Polish investors in many cases.

\section{The Neubrandenburg Chamber of Commerce and Industry}

The local Chamber of Commerce and Industry (Industrie- und Handelskammer, abbr.: IHK) is situated in the city of Neubrandenburg and covers the two counties of Mecklenburg: Lake District and Cispomerania-Greifswald, including the former county of Uecker-Randow. As all economic chambers in Germany, it is an institution under public law which incorporates all enterprises and craftsmen of that region (Fig. 2). The IHK gives company founders advice on financing and administrative formalities, and offers further education programmes in business administration from which also investors from abroad may benefit (IHK 2014). According to an IHK representative, those services are also available for Polish entrepreneurs, but are not target in the course of any particular recruitment campaigns, except booklets in the Polish language (IHK Agent, 2012). Of particular interest for our analysis are the two explicitly Poland-oriented institutions associated with and/or initiated by the IHK.

Firstly, the House of Economy (Haus der Wirtschaft/ Dom Gospodarki) in Szczecin describes itself as a "catalyst for the European integration process" and arranges business ties between German and Polish enterprises by means of instruments like web-based online exchange and contact fora. Those virtual spaces are predominantly used by Polish businesses interested in the German market and searching for German cooperation partners. However, some of those contacts might theoretically turn into a direct investment or a joint venture, and therefore this exchange could stimulate Polish investments in Germany. Quantitative data or reliable empirical evidence with regard to those issues are not available. With regard to foreign direct investments, according to an agent from that institution, the House of Economy is merely directed towards German investors doing business in Poland and offers information and a variety of assistance measures (IHK Agent, 2012). Therefore, it fulfils functions rather similar to those of a foreign trade chamber and is not relevant for Polish investors (IHK 2013b).

Secondly, another institution whose target is to intensify relations between Polish and German enterprises is represented by the German-Polish Business Circle (Deutsch-Polnischer Wirtschaftskreis), which has been holding meetings once a month in Szczecin since 2001. With a wide array of political and economic topics, these events provide both information and networking opportunities for different stakeholders (IHK 2010). Nonetheless, none of the institutions associated with the IHK mentioned above provide a distinct pro-active attraction for Polish investors to Germany.

While comparing with other IHKs located at the Polish-German border, we found that nearly every chamber - with the exception of the IHK Dresden - offers advice for one direction only, i.e. for German investors interested in business activities in Poland. The chambers arrange cooperation between companies from both countries, but none of those institutions addresses explicitly potential Polish investors in Germany. Interestingly, the Polish Chamber of Commerce in Germany was founded about five years ago by some 
renowned Polish enterprises and has its domicile in Düsseldorf, i.e. far away from the study region (Polska Izba... 2013). Therefore, it can be assumed that there is neither a well developed network of Polish chambers abroad, nor an effective assistance for small or medium-sized enterprises in the peripheral region.

\section{The Uecker Region Development Agency}

In comparison with the IHK, the Uecker Region Development Agency Ltd. (Förder- und Entwicklungsgesellschaft Uecker-Region $\mathrm{mbH}$, abbr.: FEG,) situated in Pasewalk, is more locally anchored due to its territorially based competent jurisdiction restricted to the former county of Uecker-Randow. It is predominantly funded by the municipal administrations of that region (Fig. 2). One of the main objectives, apart from offering advice on funding programmes, startup management and cooperation contacts for investors, is a pro-active marketing of locational advantages of the respective district at bilateral meetings or fairs (FEG 2013b). While even Chinese investors potentially interested in the Uecker region market are explicitly addressed (FEG 2013a), a pronounced assistance for Polish investors in Germany could not be found on the official website. But as an FEG agent told us in an interview, in fact, this institution tries to attract Polish investors in a pro-active way via presence at trade shows and round tables (FEG Agent, 2012). For instance in 2004, in close collaboration with the service centre of the Pomerania Euroregion in Pasewalk and the Euro Info Centre in Szczecin, the FEG organised an event in Szczecin which explicitly addressed Polish entrepreneurs interested in direct investment in Germany. They were informed about the procedures of founding start-ups in Germany and the potentials of the Uecker-Randow region (Pomerania 2004). But the FEG does not limit itself to Polish investors; for instance, they also recruit and assist several entrepreneurs from southern Germany and Hamburg (FEG Agent, 2012). Even if this institution seems to focus more on Polish investors in Germany than other formal institutions, one can observe a lack of communication and orchestration of services among those economic governance bodies.

\section{Informal institutions supporting Polish entrepreneurs in the border region}

While the services offered by formal institutions explicitly to Polish investors can be seen as little pronounced, some informal institutions try to fill this gap - not necessarily motivated by business acumen or profits only, but often by privation and personal fortunes of the recipients. This shows that also autonomous actors that do not belong to governmental institutions can contribute with their networks to the whole governance process (Padioleau 2000: 69). Informal institutions in Uecker-Randow, for example, are individuals such as a real-estate agent, a pub owner and the mayor of a border town, whose services will be presented as case studies in what follows.

\section{The real-estate agent}

The activities of one real-estate agency known in the region, situated just at the Polish border in Germany and run by a Polish agent, can be seen as very useful from the perspective of Polish investors in the border area. The operation services of the agency cover the German border zone of the counties of Uckermark (in Brandenburg) and Uecker-Randow (in Mecklenburg-Cispomerania). Services include the sale and rental of houses, plots and apartments. In 2007, the then Polish entrepreneur and today's real-estate agent decided to settle down with his family in a small German hamlet. One year later he opened his business. At the same time, from 2008 to 2011 there was a big interest in the sale of mainly residential buildings within German border communities. Generally, according to the agent's statement, $10 \%$ of his clients are Germans and 90\% are Poles, mostly from Szczecin and its hinterland. The agent observed that Polish citizens who migrated to the German borderland were willing to buy property and at the same time often to start a business, usually registered at the place where they lived before (i.e. in Poland). However, in recent years, the agency receives more and more inquiries from small Polish companies. In the opinion of the agent, the border region is mainly of interest to Polish micro-en- 
terprises with up to three employees who consider the geographical proximity to Szczecin as an important factor. The biggest obstacle for most of these entrepreneurs is usually lack of knowledge of the German language. Therefore, the real-estate agency seems to be of particular interest to Polish investors, providing them with consulting services in Polish and understanding the German administrative paperwork (Polish real-estate agent, 2012).

The procedure of setting up a business in Germany is a complicated task for private Polish investors as the authorisation process to carry out business activities in a desired location can take a significant period of time. This is one of the reasons why some potential Polish investors undertake investments in Polish regions instead. Moreover, institutions like tax offices, health care or chambers of commerce, the membership of which is mandatory in Germany, work differently than in Poland and demand language expertise, time and financial resources. In such cases, the agent assists by informing investors how to solve upcoming issues. He also helps in dealing with the authorities and banks (Polish real-estate agent, 2012).

Additionally to this specific professional expertise and assistance in the real-estate sector, the agent is an excellent example of a successful establishment of a functioning private business run by a Polish owner in the German border region. The success story requires a good knowledge of the region as well as a dense personal network, which can also be very useful for more Polish people and/or clients starting economic activities in Germany. Polish micro-entrepreneurs often use the agent's advice, cherishing personal contact and relationships resulting in a climate of mutual trust. Many Polish entrepreneurs, like a local Polish construction company or a Polish company in the care-for-the-elderly industry, have benefited from the agent's expertise in the past. This kind of trust is considered to be built on strong ties and frequent meetings, and can hardly be realised through spontaneous, sporadic and often impersonal contacts with agents from formal institutions. The importance of this quasi-institution for Polish investors seems to be tremendous, although, in our opinion, the interviewee was not fully aware of this (Polish real-estate agent,
2012). The agent serves as a good example of how informal institutions may fill out gaps that are a consequence of infant, newly-formed and uncoordinated multi-lateral formal governance institutions and structures reacting very rigidly to new trends, like Polish investments in Germany.

\section{The mayor}

Regardless of his official position, the mayor of a German border town in Cispomerania also acts as an informal institution for Polish investors in his responsibility area. Here, Polish companies have been present since 2004, therefore he can be seen as a pioneer and gatekeeper. The mayor's strategy for Polish investors seems to be simple and effective: on the one hand, he maintains regular contact with Polish entrepreneurs during the establishment phase and the first phase of business development, meets with potential investors from Poland to discuss aspects of their relocation to Germany, and helps in dealing with the authorities. His help to possible investors and expertise lead to investments that may create jobs in the town. On the other hand, the mayor ensures that Polish investors feel comfortable and have a sense of security while making investment decisions. The increased difficulty to gain larger investors from western regions of Germany or other countries forces the mayor to attract every potential investor through a detailed and prepared localisation and financial support where even assistance for application is provided. Moreover, he is a "focal figure and boundary spanner" by dealing with government officials and banks (Mayor, 2012).

As an elected representative of his town, the mayor acts to some extent as a formal institution. In this function he takes part in official negotiations with investors and informs them about economic opportunities in his town. Typically, the commitment of mayors in the German part of the border region is quite small in this respect. Many of them do not see talks with potential investors as one of their primary tasks. Instead, they refer to formal institutions of German-Polish economic cooperation. Mayors get only involved in investors' assistance if they engage themselves with high personal commitment in various informal activities. This commitment usually goes 
far beyond their formal responsibilities. When a mayor gives personal advice to an investor (e.g. helping him to get funding from a local bank), he will do so informally. In this respect the mayor's practice of action may change between formal and informal. In the border region we observed, however, that those mayors were most successful in attracting and assisting new firms who used diverse channels of informal practices apart from their formal work. In sum, the mayor is another example of how an informal institution may assist Polish entrepreneurs in a way that larger formal institutions do not offer. Due to his vast experience, extensive contacts and openness, his services are certainly a big bonus to Polish entrepreneurs setting up business in the German border area.

\section{The pub owner and real-estate agent}

Another informal institution that offers services to Polish investors is a Polish pub owner who also works as a real-estate agent. Together with her husband, she runs a German pub in a small border town. It is a meeting place for both Poles and Germans from the surrounding area. It is used primarily for cultural events and hosts a variety of art and youth projects, e.g. German and Polish children can exhibit their work. In the meantime, she was able to revive the shrinking and ageing German community by offering diverse services to interested young Polish families who wanted to settle and start business here. As in the case of the real-estate agent presented above, she provides business consultancy mainly based on everyday concerns for Poles who do not speak German. At the same time, she acts like a rich forge of information especially for micro-entrepreneurs from Poland, contributing to the decision-making process of both, those investing in Germany and those moving there with their families. The pub owner mediates contacts with the authorities and banks, and provides valuable information and comments related to the fundamental issues of insurance and taxes, administrative and legal accounts. In her opinion, formal institutions and their paperwork-intensive and complex promotion measures lie beyond the capacity of day-to-day needs of potential Polish micro-entrepreneurs (Polish pub owner, 2012).

\section{Polish investors and their engagement of institutions}

On the basis of the joint fieldwork of Eberhard Karls University in Tübingen and Humboldt University in Berlin in 2012, it could be proved that $100 \%$ of Polish investments in this border region were SMEs, whereas a vast majority of Polish investments in the region were private single economic activities and micro-enterprises with 2-3 employees (IHK, 2012). In the municipality of Löcknitz-Penkun, for example, by far the most of the Polish businesses belong to the trading sector, followed by dry construction and household helpers (Fig. 3). All of those businesses either consist of self-employed Poles or small enterprises with very few employees. With the introduction of a full freedom of movement for workers between Germany and Poland in 2011, some fluctuations occurred among Polish enterprises (Akman, Akman 2013). For example, in one border town, seven Polish companies closed their operation, but were soon replaced by new entrepreneurs. This can be explained by the fact that some of the people working so far on the German market officially as one-man businesses can now work in the companies for which they previously provided services (Mayor, 2012). While visiting addresses from our database where Polish companies ought to be located, in some cases we only found 'letter-box companies', mostly operating as housekeepers or geriatric nurses in parts of south or west Germany. Those enterprises need an official administrative recording and indexing, and a physical address in Germany due to legal requirements (taxes, health care, etc.), and they benefit from 'middlemen' living in Poland completing their paperwork or simply obtaining tax advantages. Others benefit from the 'made in Germany' label if they advertise and sell certain products elsewhere (FEG Agent, 2012).

Interviews with selected local enterprises in the region brought to the fore the fact that the proximity to Szczecin often influenced the choice of investment in the region. In most of those cases, Polish investors first settled in the study region and later decided to establish a business there. A real-estate broker pointed out that investment decisions of Polish investors in 


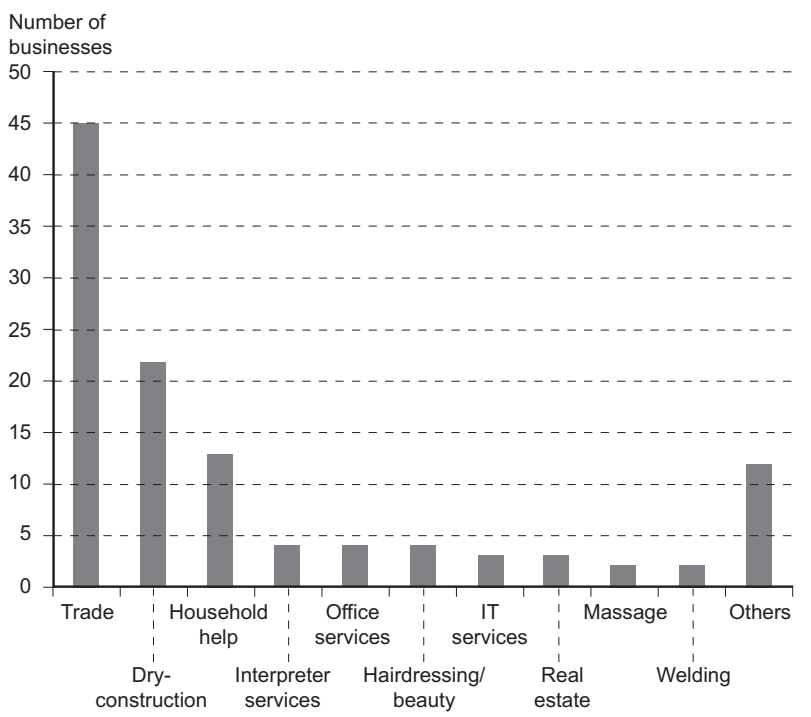

Fig. 3. Polish businesses in the municipality of Löcknitz-Penkun.

Source: own compilation based on information from the municipality of Löcknitz-Penkun, 2013.

the German borderland are often linked with the decision to settle there (Polish real-estate agent, 2012). But there are also exceptions, such as a tax office or a food additives company, which operate on the German market but the entrepreneurs commute to work from Poland (Polish tax office, 2012). Another example is an enterprise whose owner lives in the same town but runs two companies, one on the German side of the border and the other in Poland (Polish entrepreneur, 2012). Other motivations for investments in Cispomerania are higher wages obtained for services (elderly care, etc.), investment subsidies, or the effect of the 'made in Germany' label allowing export to western Europe.

According to the mayor of a border town, Poles are more flexible than Germans and fill particular market niches faster. About $30 \%$ of Polish companies often make changes, like the transfer of business to another location or adjustments to the market. They are aware of the competitiveness of the local economy and provide services in industries that are often not of interest to Germans. Poles are also more willing to learn the German language and work in the afternoons, evenings and at weekends, which could be one of the reasons why the majority of Polish companies operating in the region usually employ Polish workers (Mayor, 2012).

In many cases, before Polish investors make the decision to invest in the German border re- gion, they inform themselves about the market on the basis of the formal institutions discussed above. Some entrepreneurs also benefit from start-up programmes. These include different measures (subsidies, cheap loans for setting up a company) provided by the IHK, like a tax office that got a financial grant during the first one and a half years of operation (Polish tax office, 2012). Interestingly, none of the Polish entrepreneurs in our sample has benefited directly from programmes of the Pomerania Euroregion, with the exception of infrastructure projects. Two entrepreneurs even considered this institution to be too bureaucratic (Polish pub owner, 2012; Polish real-estate agent, 2012). The mentality of Polish micro-entrepreneurs implies that personal contact with people who are already familiar with doing business in that region is very important because they may share their knowledge and experiences. It is important to establish relations with quasi-institutions like the ones presented above. They do not rely on one single contact, but provide information and answers to key questions related to the running of a business in Germany at the very beginning.

Still, there are some barriers which greatly hinder the setting up of Polish companies in the region. Very important in this respect is the cultural difference between Poles and Germans; their lack of this type of knowledge often hampers their functioning on the German market (Mayor, 2012). We still consider that a large fraction of neo-Nazis, which often turn their actions against the Polish population in a town and the surrounding villages, has a negative impact and probably effectively discourages potential investors from Poland. A major factor for neo-Nazi actions is the jealousy of some local residents gazing on ambitious and dynamic Poles developing their businesses. However, some gradual positive changes could be observed along with more frequent contacts with Poles.

\section{Conclusions}

Table 4 summarises the results of a SWOT analysis focusing on the potential for economic and demographic development in Uecker-Randow with particular regard to Polish investors and 
immigrants. In this case, the strengths and weaknesses refer to location-specific advantages and disadvantages for Polish investors that can be observed right now, while the opportunities/ threats section takes into consideration possible changes in the future. As one can see, there is potential for both positive and negative regional development. Our research has revealed that Polish immigrants residing in the German border region may indeed increase the number of inhabitants. Since the bulk of immigrants are families, this fact may turn the demographic trend of the ageing population. Also the real-estate vacancy rate has already been reduced by Polish property buyers so far.

However, with regard to the economic impact of Polish entrepreneurship, we found that those investments were made predominantly by micro-enterprises or self-employed people that do not create either employment on any large scale or a critical mass for stable growth. However, entrepreneurs in basic retail (e.g. groceries, bakeries) and services (care for the elderly) may improve local supply in a region affected by loss of population and infrastructure. One interviewee even complimented the flexibility and work ethic of Polish entrepreneurs. The examples of larger Polish enterprises being often referred to in the media - as mentioned in the introduction - turned out to be rather exceptions. The findings in Uecker-Randow match the general trend of Polish investment in Germany being much less distinct in terms of volume than the other way around. Also at the scale of the Pomerania

Table 4. SWOT analysis of Uecker-Randow with regard to Polish entrepreneurs.

\begin{tabular}{|c|c|}
\hline Strengths & Weaknesses \\
\hline $\begin{array}{l}\text { - investment grants } \\
\text { - preferential loan programmes of German banks } \\
\text { - informal counselling institutions in cross-border busi- } \\
\text { ness (mostly individuals) } \\
\text { - presence of trained advisors in region (business, tax, } \\
\text { financial consulting) } \\
\text { - Polish-speaking staff in local offices and banks (in case } \\
\text { there is such staff employed) } \\
\text { - geographical proximity to Szczecin } \\
\text { - good road access, access to motorway network } \\
\text { - Poland's access to Schengen Agreement } \\
\text { - inexpensive real estate } \\
\text { - effect of 'Made in Germany' }\end{array}$ & $\begin{array}{l}\text { - poor quality of Polish-German cooperation at level of } \\
\text { formal institutions } \\
\text { - lack of direct recruitment of potential investors from } \\
\text { Poland } \\
\text { - economically underdeveloped region } \\
\text { - impact of Szczecin on regional economy lower than } \\
\text { expected } \\
\text { - dominance of public sector in region - no outlets in } \\
\text { region } \\
\text { - lack of proper investment climate } \\
\text { - ageing of local population } \\
\text { - no common citizen identity } \\
\text { - Polish-German prejudices } \\
\text { - poor knowledge of German and Polish among major- } \\
\text { ity of local population } \\
\text { - majority of inhabitants have poor skills in intercultur- } \\
\text { al communication }\end{array}$ \\
\hline Opportunities & Threats \\
\hline $\begin{array}{l}\text { - formal institutions increasingly aware of Polish inves- } \\
\text { tors } \\
\text { - addressing concrete potential investors } \\
\text { - further development of Szczecin Metropolitan Area } \\
\text { - construction of western bypass of Szczecin, Szczecin } \\
\text { better connected with German border communities } \\
\text { - development of regional academic centres in Szczecin, } \\
\text { Greifswald and Neubrandenburg } \\
\text { - introduction of Euro currency in Poland } \\
\text { - further development of Polish settlement in border } \\
\text { communities of Germany, leading to compensation of } \\
\text { - demographic trend } \\
\text { - better language skills of Polish and German youth } \\
\text { - strengthening Polish-German relations of good neigh- } \\
\text { bourhood } \\
\text { - increase in cross-border awareness of region's popu- } \\
\text { lation }\end{array}$ & $\begin{array}{l}\text { - formal institutions ignoring Polish investors } \\
\text { - phasing-out of funding programmes } \\
\text { - lack of coherent regional development strategy } \\
\text { - further orientation of Szczecin towards large German } \\
\text { agglomerations like Berlin and Hamburg } \\
\text { - decline of Szczecin as regional social-economic centre } \\
\text { - maintenance of bad investment climate in border re- } \\
\text { gion } \\
\text { - continuing unfavourable demographic trend } \\
\text { - persistence of mutual prejudices } \\
\text { - lack of language and cultural skills in majority of pop- } \\
\text { ulation }\end{array}$ \\
\hline
\end{tabular}

Source: own compilation on the basis of own research, 2013. 
Euroregion, other studies confirm our findings. "There are several German direct investments in the Szczecin region. Especially the special economic areas in the region benefited from them, but investors did not come from the border region. There have been rarely any larger Polish investments in Cispomerania" (Maack 2010: 42 ff.).

Besides such disadvantages as lack of a highly educated labour force, lack of language skills, and existing prejudices (Table 4), one of the reasons that may hinder Polish investors could be lack of governance mechanisms. At first, we identified a mixture of formal and informal institutions. While the formal institutions are either public or under public law, the informal institutions in our sample are solely individuals. With regard to formal institutions, we could hardly find any offers explicitly addressed to Polish investors except the presence of the FEG at some trade shows and round-table meetings, not officially communicated. Even if Polish entrepreneurs could benefit from a general assistance of public institutions, the interviews revealed that some Polish investors considered those institutions to be too bureaucratic. Instead, Poles seem to prefer informal institutions that give more assistance via personal advice and their local networks. We could hardly identify any interaction between the formal and the informal government sphere. This is why one can classify those informal institutions as a self-governance type of governance (Kooiman 2003) existing in parallel to the sphere of various formal institutions.

In order to further diminish investment barriers for Polish entrepreneurs, formal institutions would be well advised to realise the potential of Polish investors and explicitly address them, including services in the Polish language and recruitment among communities of potential investors. Thus, formal institutions could influence the development of the border region in a positive way.

\section{References}

Akman A., Akman I., 2013. Die Arbeitnehmerfreizügigkeit zwischen Deutschland und Polen - eine Betrachtung von theoretischen Möglichkeiten und faktischer Migration polnischer Arbeitnehmer und Arbeitgeber seit 2004 (Freedom of movement for workers between Germany and Poland - an analysis of theoretical possibilities and de facto migration of Polish employees since 2004). In: Suwala L., Peiker W. (eds), Internationalisierung vor der Haustür - Polnische Investoren in Ostvorpommern. Arbeitsbericht des Geographischen Institutes, Berlin: 29-39.

Amt Löcknitz-Penkun, 2013. Polnische Gewerbetreibende (Polish businessmen). As of 31 May 2013.

Barjak F., 2001. Regional disparities in transition economies: a typology for East Germany and Poland. Post-Communist Economies 13 (3): 289-311.

Botschaft der Bundesrepublik Deutschland Warschau, 2012. Daten zur Polnischen Wirtschaft (Key figures of the Polish economy). As of 1 Oct. 2012. http:/ / www.warschau. diplo.de/contentblob/3421896/Daten/2751083/Statistikpdf.pdf (last accessed 22 April 2013).

Deutsche Bundesbank, 2012. Direktinvestitionen lt. Zahlungsbilanzstatistik (Direct investment according to balance of payments statistics). Berichtsraum 2008 bis 2011. As of April 2012.

Fitoussi J., Saraceno F., 2013. European economic governance: The Berlin-Washington consensus. Cambridge Journal of Economics 37 (3): 479-496.

Einig K., Grabher G., Ibert O., Strubelt W., 2005. Urban governance. Informationen zur Raumentwicklung 09/10: I-IX.

Förder- und Entwicklungsgesellschaft Uecker-Region, 2013a. Dienstleistungsnetzwerk für chinesische Investoren im Nordosten Deutschlands (Service network for Chinese investors in northeastern Germany). http://www. feg-vorpommern.de/de/regionalangebote/ investorennetzwerke/dienstleistungsnetzwerk-fur-chinesische-investoren-im-nordosten-deutschlands.html (last accessed March 2013).

Förder- und Entwicklungsgesellschaft Uecker-Region, 2013b. Leistungsinhalt FEG (Benefits from FEG). http:// www.feg-vorpommern.de/de/leistungsinhalt-feg.html (last accessed March 2013).

Fürst D., 2003. Steuerung auf regionaler Ebene versus Regional Governance. Informationen zur Raumentwicklung 8/9: 441-450.

GUS, Główny Urząd Statystyczny, 2012. Concise Statistical Yearbook of Poland 2012. ZWS, Warsaw.

Heddebaut O.,2004. The Euroregion from 1991 to 2020: an ephemeral stamp? In: Kramsch O.T., Hooper B. (eds), Cross-border governance in the European Union. Routledge, London: 121-134.

Hirst P., 2000. Democracy and governance. In: Pierre J. (ed.), Debating governance. Authority, steering and democracy. Oxford University Press, New York: 13-35.

Hooghe L., Marks G., 2001. Types of multi-level governance. European Integration online Papers (EIoP), 5 (11).

IHK Neubrandenburg, 2010. Deutsch-Polnisches Projekt "Haus der Wirtschaft" von historischer Tragweite (German-Polish project "House of Economy" of historical importance). http:/ / www.neubrandenburg.ihk.de/ index. php?id=5067\#c16385 (last accessed March 2013).

IHK Neubrandenburg, 2012. The Uecker-Randow development agency based on business registers from municipal offices.

IHK Neubrandenburg, 2013a. IHK Neubrandenburg für das östliche Mecklenburg-Vorpommern (IHK Neubrandenburg for Eastern Mecklenburg-Vorpommern). http:// www.neubrandenburg.ihk.de/index.php?id=4\&no_ cache=1 (last accessed March 2013).

IHK Neubrandenburg, 2013b. Das Haus der Wirtschaft - Regionen wachsen zusammen (The House of Economy - re- 
gions are merging). http:// www.neubrandenburg.ihk. de/index.php?id=1594 (last accessed March 2013).

Kaczmarek T., Stryjakiewicz T., 1997. Die Formen der sozialen und wirtschaftlichen Aktivität im deutsch-polnischen Gebiet (Forms of social and economic activity in the German-Polish area). In: Eckart K., Kowalke H. (eds), Die Euroregionen im Osten Deutschlands. Duncker \& Humblot, Berlin: 29-47.

Kjaer A., 2004. Governance. Polity Press, Cambridge.

Kooiman J., 1993. Modern governance. New government-society interactions. Sage Publications, London.

Kooiman J., 2003. Governing as governance. Sage, London.

Kramsch O.T., Hooper B., 2004. Introduction. In: Kramsch O.T., Hooper B. (eds), Cross-border governance in the European Union. Routledge, London: 1-22.

Krätke S., Borst R., 2004. Die deutsch-polnischen Wirtschaftsbeziehungen als Chancen für die Region Berlin-Brandenburg. Perspektiven eines regionalen Kompetenzzentrums für Ost-West-Kooperation im Rahmen der EU-Osterweiterung (German-Polish economic relations as a chance for the Berlin-Brandenburg region. Perspectives of a regional centre of competence for East-West cooperation in the context of EU eastern expansion). Otto-Brenner-Stiftung, Berlin.

Kuiper J., 2007. Hilfe, die Polen kommen! (Help - the Poles are comming!) www.freitag.de/ autoren/ der-freitag/hilfedie-polen- kommen (last accessed 16 Nov. 2012).

Maack K., 2010. Wachstumspol Stettin: Entwicklung der deutsch-polnischen Grenzregion. Aktualisierung der Studie "Wachstumspol Stettin und Auswirkungen auf die Entwicklung der deutsch-polnischen Grenzregion" (2004) (The Szczecin growth pole: Development of the German-Polish border region. Update of the study "The Szczecin growth pole and implications for the development of the German-Polish border region", 2004). http:/ / www. boeckler.de/ pdf_fof/S-2009-320-1-1.pdf (last accessed 22 April 2013).

Maack K., Grundmann M., Kreft J., Lewandowska A., Voß E., 2005. Wachstumspol Stettin und die Auswirkungen auf die Entwicklung der deutsch-polnischen Grenzregion (The Szczecin growth pole and implications for the development of the German-Polish border region). Edition der Hans-Böckler-Stiftung, Düsseldorf.

Neuser J., Wicke P., 2013. Polnische Investoren in Ostvorpommern im Blickfeld der Medien: ein Pressespiegel (Polish investors in Eastern Cispomerania in the media focus: a press review). In: Suwala L., Peiker W. (eds), Internationalisierung vor der Haustür - Polnische Investoren in Ostvorpommern. Arbeitsbericht des Geographischen Institutes, Berlin: 99-107.

Padioleau J.G., 2000. La gouvernance ou comment s'en débarrasser (Stratégies de corruption) (Governance or how to get rid of it (strategies of corruption)). Espaces et Sociétés 101-102: 61-73.

Pierre J., 2000. Debating governance. Authority, steering and democracy. Oxford University Press, New York.

Polska Izba Gospodarcza w Niemczech, 2013. O nas (About us). http:// pwdorg.org/doc_firma.html (last accessed Feb. 2013).

Pomerania, 2004. Unternehmensgründung in Deutschland - die Region am Stettiner Haff stellt sich vor (Start-ups in Germany - the region at the Szczecin Lagoon presenting itself). http:// www.pomerania.net/ main.cfm?rubrik $=2 \&$ th $=$ 29\&archiv $=$ news\&anewsid $=404$ (last accessed March 2013).
Pomerania, 2013a. Euroregion - Aims/Tasks. http:// www. pomerania.net $/$ main.cfm? $1=$ en\&rubrik $=5 \&$ th $=31$ (last accessed March 2013).

Pomerania, 2013b. Kontakt- und Beratungsstelle (Contact and advice centre). http:// www.pomerania.net/ main.cfm?1 $=$ de\&rubrik $=5 \& t h=71$ (last accessed March 2013).

Pomerania, 2013c. Geschäftsstelle der Kommunalgemeinschaft POMERANIA e.V. (Office of the Municipality Association POMERANIA) http:/ / www.pomerania.net/ main. $\mathrm{cfm} ? 1=$ de\&rubrik=5\&th=34\#36 (last accessed March 2013).

Pomerania, 2014. Euroregion - Fundamentals. http:/ / www.pomerania.net $/$ main.cfm? $1=$ en\&rubrik $=5 \& \mathrm{th}=30 \& \mathrm{~b}=\mathrm{eu}-$ roregion_gesamt (last accessed Nov. 2014).

Ricq C., 1992. Les régions frontalières et l'intégration européenne (Border regions and European integration). Livre blanc de l'ARE. Centre d'Observation Européen des Régions.

Robak J., 2011. Wirtschaftsstandort Deutschland - Stand der polnisch-deutschen Beziehungen (Business location Germany state-of-the-art of the Polish-German relations). Botschaft der Republik Polen in der Bundesrepublik Deutschland, Berlin.

Schamp E.W.,1995. Die Bildung neuer grenzüberschreitender Regionen im östlichen Mitteleuropa - eine Einführung (Creation of new cross-border regions in East-Central Europe). In: Gruber G., Lamping H., Lutz W., Schamp E.W. (eds), Neue grenzüberschreitende Regionen im östlichen Mitteleuropa. Institut für Wirtschafts- und Sozialgeographie. Johann Wolfgang Goethe-Universität, Frankfurt (Main): $1-18$.

Schuppert G.F. (ed.), 2005. Governance-Forschung. Vergewisserung über Stand und Entwicklungslinien (Governance research. A look at the state-of-the-art and development directions). Nomos, Baden-Baden.

Sparke M., 2006. Political geography: political geographies of globalization (2) - governance. Progress in Human Geography 30 : $357-72$.

Statistisches Amt Mecklenburg-Vorpommern, 2010. Zahlenspiegel Mecklenburg-Vorpommern (Data compilation on Mecklenburg-Cispomerania). Oktober 2010.

Statistisches Amt Mecklenburg-Vorpommern, 2012. Special statistical compendium obtained from Förder- und Entwicklungsgesellschaft. Uecker-Region.

Stryjakiewicz T., 2002. Chancen und Probleme der Entwicklung im deutsch-polnischen Grenzraum (Development chances and problems in the German-Polish border area). In: Neuss B., Jurczek P., Hilz W. (eds), Europäische Integrationsbestrebungen auf politischer und regionaler Ebene - Tschechien und Polen. Europäisches Zentrum für Föderalismus-Forschung, Tübingen: 42-58.

Thiemann I., Wockenfuß J., 2013. Wirtschaftliche und demographische Entwicklung des ehemaligen Landkreises Uecker-Randow seit 1990 (Economic and demographic development of the former district of Uecker-Randow since 1990). In: Suwala L., Peiker W. (eds), Internationalisierung vor der Haustür - Polnische Investoren in Ostvorpommern. Arbeitsbericht des Geographischen Institutes, Berlin: 64-74.

Trentmann N., 2011. Polen verhelfen ostdeutschem Dorf zu neuer Blüte. www.welt.de/ wirtschaft/ article13277174/Polen-verhelfen-ostdeutschem-Dorf-zu-neuer-Bluete.html (last accessed 15 Nov. 2012).

Virtanen P., 2004. Euregions in changing Europe: Euregion Karelia and Euroregion Pomerania as examples. In: 
Kramsch O.T., Hooper B. (eds), Cross-border governance in the European Union. Routledge, London: 121-134.

Zimny Z., 2012. Inward FDI in Poland and its policy context, 2012. Columbia FDI Profiles, April 24, 2012. http:// www.vcc.columbia.edu/ files/ vale/ documents/ Poland_IFDI_-_FINAL_-_2012_24_April_2012.pdf (last accessed 21 April 2013).

\section{Interviewees}

Agent from the Förder- und Entwicklungsgesellschaft Uecker-Region, 2012.

Agent from the IHK Neubrandenburg, 2012.

Mayor of a town in West Pomerania, 2012.

Polish entrepreneur in West Pomerania, 2012.

Polish owner of a pub in West Pomerania, 2012.

Polish real-estate agent in West Pomerania, 2012.

Polish tax office in West Pomerania, 2012. 